\title{
Epitope specificity of anti-Adrenomedullin antibodies determines efficacy of mortality reduction in a cecal ligation and puncture mouse model
}

\author{
Joachim Struck ${ }^{1 *}$, Frauke Hein ${ }^{1}$, Siegmund Karasch ${ }^{2}$ and Andreas Bergmann ${ }^{1}$
}

\author{
* Correspondence: jstruck@ \\ adrenomed.com \\ ${ }^{1}$ AdrenoMed AG, Neuendorfstr. 15a, \\ Hennigsdorf 16761, Germany \\ Full list of author information is \\ available at the end of the article
}

\begin{abstract}
Introduction: Adrenomedullin (ADM), a circulating vasodilatory peptide, plays an important role in the development of sepsis-associated hemodynamic and microcirculatory disorders. While administration of exogenous ADM had beneficial effects in several septic animal models, elevated ADM concentrations are associated with a bad outcome. This prompted us to test the effect of various anti-ADM antibodies in a cecal ligation and puncture (CLP) mouse model.

Methods: To gain new potential compounds for the treatment or prevention of septic shock we followed an alternative strategy to influence the ADM system: High-affinity anti-ADM antibodies with different epitope specificities were developed and their antagonist activity in vitro and their ability to reduce mortality in a CLP mouse model were assessed.

Results: An anti-ADM antibody directed against the $\mathrm{N}$-terminus substantially increased the survival of mice in a CLP model ( $\mathrm{HR}=0.077(\mathrm{Cl}=0.0189$ to 0.315$)$, $p=0.0004)$, whereas other antibodies with similar affinities but different epitope specificities were much less potent. The efficacious antibody, in contrast to an anti-C-terminal antibody, only partially inhibited ADM agonist activity in vitro. Healthy mice were not negatively affected by the N-terminal antibody.
\end{abstract}

Conclusions: An anti-N-terminal ADM antibody, as opposed to antibodies with other epitope specificities, strongly reduces mortality in CLP mice.

Keywords: Adrenomedullin; Sepsis; Therapy; Animal model; Monoclonal antibodies

\section{严 Springer}

\section{Introduction}

Despite advances in supportive care, each year 750,000 people develop sepsis and 225,000 die in the USA alone, and the incidence of sepsis is rising at rates between $1.5 \%$ and $8 \%$ per year [1-3]. Sepsis is a complex and dynamic condition initiated by an infectious stimulus and proceeding to an exaggerated systemic immune response $[4,5]$. Several approaches in the past two decades to improve sepsis-associated mortality by novel therapies have had only limited only [6-10].

The peptide adrenomedullin (ADM) has been implicated in the development of septic shock: It is important in initiating the hyperdynamic response during the early

(c) 2013 Struck et al.; licensee Springer. This is an Open Access article distributed under the terms of the Creative Commons Attribution License (http://creativecommons.org/licenses/by/2.0), which permits unrestricted use, distribution, and reproduction in any medium, provided the original work is properly cited. 
stage of sepsis, and the reduced vascular responsiveness to ADM is associated with the transition from the hyperdynamic phase to the hypodynamic phase during the progression of sepsis [11-14].

ADM comprises 52 amino acids and is secreted into the blood stream from a variety of tissues [15-17]. ADM has multiple functions, the most prominent being its vasodilatory activity. It acts on vascular smooth muscle cells and vascular endothelial cells by binding to a $G$ protein-coupled receptor system composed of the calcitonin receptor-like receptor (CRLR) and an accessory protein (receptor activity-modifying protein (RAMP) 2 or 3) via downstream cyclic adenosine monophosphate (cAMP) and NO signaling. In several preclinical studies exogenous ADM reduced mortality from septic shock and multiple organ failure (MOF) by reducing vascular hyperpermeability, preventing endothelial cell dysfunction and down-regulating the inflammatory response [12,18-21].

Apparently, in contrast to the reported beneficial effects of ADM in sepsis, ADM has been categorized as a cardiac depressant factor in sepsis: ADM (22-52), an ADM receptor antagonist, improved the contractility of myocytes isolated from lipopolysaccharide (LPS)-treated rats. In addition, an anti-ADM antiserum improved the survival of LPS-treated rats [22].

Plasma levels of circulating ADM are relatively stable throughout various clinical conditions [23]. The strongest elevations have been observed in severe sepsis and septic shock, where increased ADM levels are associated with fatal outcome [24-26], suggesting that excessively high concentrations of ADM can be detrimental. In the present study, we assessed whether certain antibodies against ADM are potentially suitable therapeutic compounds to reduce sepsis-associated mortality in a cecal ligation and puncture mouse model, and how their efficacy in the animal model is associated with their affinities, epitope specificities, and antagonist activities.

\section{Material and methods}

\section{Development of mouse monoclonal anti-ADM antibodies}

Antipeptide antibodies were generated and selected by standard procedures (Unicus OHG, Karlsburg, Germany): Peptides were synthesized, as listed in Table 1 (JPT Technologies $\mathrm{GmbH}$, Berlin, Germany). An additional N-terminal cysteine residue was added if no cysteine was present within the selected ADM-derived sequence. The peptides were conjugated to maleimide-activated bovine serum albumin (BSA). BALB/c mice were immunized with $100 \mu \mathrm{g}$ of peptide-BSA conjugate per animal at days 0 and 14

Table 1 Overview on monoclonal anti-ADM antibodies and their characteristics

\begin{tabular}{llllll}
\hline Antibody \# & Immunogen & $\begin{array}{l}\text { Amino acid position } \\
\text { of immunogen in } \\
\text { adrenomedullin }\end{array}$ & $\begin{array}{l}\text { IgG } \\
\text { subtype }\end{array}$ & Kd (M) & $\begin{array}{l}\text { Maximal inhibition } \\
\text { in bioassay (\%) }\end{array}$ \\
\hline NT-M & YRQSMNQGSRSNGCRFGTC & $1-19$ & $2 \mathrm{a}$ & $5.8 \times 10^{-9}$ & 24.0 \\
MR-M & CTFQKLAHQIYQ & $19-31$ & 1 & $5.9 \times 10^{-9}$ & 61.7 \\
CT-M & CAPRNKISPQGY-NH 2 & Cys-40-50 & $2 b$ & $9.0 \times 10^{-9}$ & 102.1 \\
NT-H & YRQSMNNFQGLRSFGCRFGTC & $1-21$ & 1 & $1.6 \times 10^{-8}$ & 25.5 \\
MR-H & CTVQKLAHQIYQ & $21-32$ & 1 & $2.0 \times 10^{-9}$ & 74.4 \\
CT-H & CAPRSKISPQGY-NH 2 & Cys-42-52 & 1 & $1.1 \times 10^{-9}$ & 100.7 \\
\hline
\end{tabular}

The antibodies were named according to their epitope specificities as follows: NT, anti-N-terminal region; MR, anti-midregion; $\mathrm{CT}$, anti-C-terminal region; and the suffixes $\mathrm{M}$ and $\mathrm{H}$ designate mouse and human $\mathrm{ADM}$, respectively. 
(emulsified in $100 \mu \mathrm{L}$ of complete Freund's adjuvant) and $50 \mu \mathrm{g}$ at days 21 and 28 (in $100 \mu \mathrm{L}$ of incomplete Freund's adjuvant). Three days before the fusion, each animal received $50 \mu \mathrm{g}$ of the conjugate dissolved in $100 \mu \mathrm{L}$ of saline, given as one intraperitoneal and one intravenous injection. Splenocytes from the immunized mice and cells of the myeloma cell line SP2/0 were fused with $1 \mathrm{~mL}$ of $50 \%$ polyethylene glycol. After washing, the cells were seeded in 96-well cell culture plates. Hybridomas were selected by growing in hypoxanthine-aminopterin-thymidine (HAT) medium (RPMI-1640 culture medium (Sigma-Aldrich, St. Louis, MO, USA) supplemented with $20 \%$ fetal calf serum and HAT Supplement (Life Technologies, Grand Island, NY, USA)). After 2 weeks, the HAT medium was replaced with HT medium for three passages followed by returning to the normal cell culture medium. The cell culture supernatants were primarily screened for antigen-specific IgG antibodies 3 weeks after fusion. The positive tested microcultures were transferred into 24-well plates for propagation. After retesting, the selected cultures were cloned and recloned using the limiting dilution technique and the isotypes were determined. Monoclonal antibodies were produced and purified by standard methods employing Protein A chromatography. The antibody purities were $>95 \%$ based on SDS gel electrophoresis analysis. Fab and $\mathrm{F}(\mathrm{ab})_{2}$ fragments were generated by standard procedures. For antibody nomenclature, see Table 1.

\section{Affinity constants}

To determine the affinity of the antibodies to human and mouse ADM, respectively, the association and dissociation kinetics of ADM binding to immobilized antibody was determined by means of label-free surface plasmon resonance using a Biacore 2000 system (GE Healthcare Europe GmbH, Freiburg, Germany). Reversible immobilization of the antibodies was performed using an anti-mouse Fc antibody covalently coupled in high density to a CM5 sensor surface according to the manufacturer's instructions (mouse antibody capture kit; GE Healthcare). Antibody binding kinetics were determined by standard procedures, and affinity constants were calculated (Biaffin GmbH, Kassel, Germany).

\section{ADM bioassay}

CHO-K1 cells expressing recombinant ADM receptor (CRLR + RAMP3 (FAST-027C; Euroscreen S.A., Brussels, Belgium) grown in media without antibiotic prior to the test were detached by gentle flushing with PBS-EDTA (5 mM EDTA), recovered by centrifugation, and resuspended in assay buffer $\left(5 \mathrm{mM} \mathrm{KCl}, 1.25 \mathrm{mM} \mathrm{MgSO}_{4}, 124\right.$ $\mathrm{mM} \mathrm{NaCl}, 25 \mathrm{mM}$ HEPES, $13.3 \mathrm{mM}$ glucose, $1.25 \mathrm{mM} \mathrm{KH}_{2} \mathrm{PO}_{4}, 1.45 \mathrm{mM} \mathrm{CaCl}_{2}$, $0.5 \mathrm{~g} / \mathrm{L} \mathrm{BSA}$ ). Dose-response curves were obtained in parallel with the reference agonists human ADM and mouse ADM. After addition of the lysis buffer, cAMP was measured with an HTRF kit according to the instructions of the manufacturer (Cis-Bio International, Bagnols, France). The dose-dependent antagonist activity of anti-ADM antibodies was determined in the presence of human ADM or mouse $\mathrm{ADM}$, respectively, either one at a predetermined concentration yielding $80 \%$ of the maximal stimulation obtainable for the cAMP response: $6 \mu \mathrm{L}$ of the reference agonist (human $(5.63 \mathrm{nM})$ or mouse $(0.67 \mathrm{nM}) \mathrm{ADM})$ was mixed with $6 \mu \mathrm{L}$ of the test samples at different antibody dilutions of $100,20,4,0.8$, and $0.16 \mu \mathrm{g} / \mathrm{mL}$. After incubation for $60 \mathrm{~min}$ at room temperature, $12 \mu \mathrm{L}$ of cells $(2,500$ cells/well $)$ 
were added. The plates were incubated for $30 \mathrm{~min}$ at room temperature, and cAMP was measured as described above. Antagonist activity of anti-ADM antibodies was calculated as percentage of inhibition relative to the maximal inhibition obtainable with the reference antagonist peptide ADM (22-52).

\section{Sepsis model (cecal ligation puncture)}

Twelve- to fifteen-week-old male C57Bl/6 mice (Charles River Laboratories, Cologne, Germany) were used for the study (Phenos GmbH, Hannover, Germany). Peritonitis had been surgically induced under light isoflurane anesthesia. Incisions were made into the left upper quadrant of the peritoneal cavity (normal location of the cecum). The cecum was exposed and a tight ligature was placed around the cecum with sutures distal to the insertion of the small bowel. One puncture wound was made with a 24-gauge needle into the cecum, and small amounts of cecal contents were expressed through the wound. The cecum was replaced into the peritoneal cavity and the laparotomy site was closed. Finally, the animals were returned to their cages with free access to food and water. Five hundred microliters of saline was given s.c. as fluid replacement.

\section{Efficacy test}

Using this CLP model, three anti-mouse ADM antibodies (NT-M, MR-M, and CT-M) were tested for their ability to modify the 14-day mortality rate in comparison to vehicle (PBS buffer) and control compound (unspecific IgG). Ten animals per compound were used. Compounds were applied i.v. immediately prior to surgery (10 $\mu \mathrm{L} / \mathrm{g}$ body weight, $0.2 \mathrm{mg} / \mathrm{mL}$ ). Mice were monitored twice daily. In a follow-up experiment, Fab- and $\mathrm{F}(\mathrm{ab})_{2}$ fragments of NT-M were tested analogously.

\section{Safety test}

Twelve- to fifteen-week-old male C57Bl/6 mice (Charles River Laboratories, Germany) were used for the study. Six mice were treated with NT-M anti-ADM antibody $(10 \mu \mathrm{L} / \mathrm{g}$ body weight; $3.0 \mathrm{mg} / \mathrm{mL})$. As control, six mice were treated with PBS $(10 \mu \mathrm{L} / \mathrm{g}$ body weight). Survival and physical condition were monitored for 14 days.

\section{Ethics}

For all animal experiments described in this manuscript, approval was obtained according to the requirements of the respective German law (Tierschutzgesetz (TierSchG)) from the Niedersächsisches Landesamt für Verbraucherschutz und Lebensmittelsicherheit (LAVES). Our study has been purely experimental and did not involve any human samples.

\section{Statistics}

Statistical significance was calculated by Student's $t$ test. For survival analysis, Kaplan-Meier curves were generated and log-rank test for significance was performed. GraphPad Prism 4 software (GraphPad Software, Inc., La Jolla, CA, USA) was used. 


\section{Results}

\section{Anti-ADM antibodies}

Several mouse monoclonal antibodies against the N-terminal, midregional, and C-terminal moieties of mouse ADM (NT-M, MR-M, CT-M) and human ADM (NT-H, MR-H, CT-H) were developed (Figure 1, Table 1). The affinity constants of the antibodies were in the range of $1.1 \times 10^{-9}$ to $1.6 \times 10^{-8} \mathrm{M}$ (Table 1 ).

The agonist and antagonist activities of the antibodies were tested in an established ADM bioassay system employing a $\mathrm{CHO}$ cell line overexpressing the human recombinant ADM receptor (CRLR + RAMP3) with a cAMP readout. None of the antibodies exhibited agonist activity in the bioassay (data not shown). The antibodies showed different dose-dependent antagonist activity profiles (Figure 2, Table 1). Surprisingly, the observed differences were dependent on the epitope specificity rather than on the affinity of the antibodies, for both the anti-human ADM and the anti-mouse ADM antibodies: The maximal obtainable inhibition of the ADM-induced cAMP response was $100 \%$ for the antibodies directed against the C-terminal moiety of ADM, around $70 \%$ for the antibodies directed against the midregional moiety of ADM, and around 25\% for the antibodies directed against the N-terminal moiety of ADM (Figure 2, Table 1).

The anti-mouse ADM antibodies were tested in a CLP sepsis mouse model for their ability to reduce mortality. The observation period was 14 days. The doses of antibodies were chosen so that concentrations in vivo should by far exceed on a molar basis the expected concentrations of endogenous plasma ADM. In the control groups (vehicle buffer or unspecific control antibody), most of the animals had died already on day 1 (Figure 3 ). The antibodies against the midregion and C-terminus of ADM improved survival slightly, but significantly, when compared to either vehicle or control (MR-M vs. vehicle: $\mathrm{HR}=0.182(\mathrm{CI}=0.760$ to 0.043$), p=0.0195$; MR-M vs. control: $\mathrm{HR}=0.201(\mathrm{CI}=0.051$ to 0.789$), p=0.0215$; CT-M vs. vehicle: $\mathrm{HR}=0.182$ $(\mathrm{CI}=0.766$ to 0.043$), p=0.0202$; CT-M vs. control: $\mathrm{HR}=0.1796(\mathrm{CI}=0.044-0.733)$, $p=0.0167)$. A strong and sustained improvement of survival was obtained with the antibody against the N-terminus of ADM: 50\% of the animals treated with this antibody survived the CLP procedure over the observation period of 14 days (Figure 3) (NT-M vs. vehicle: $\mathrm{HR}=0.068$ (CI $=0.291$ to 0.0159$), p=0.0003$; NT-M vs. control: $\mathrm{HR}=0.07717(\mathrm{CI}=0.0189$ to 0.315$), p=0.0004)$. The improvement of survival for the antibody against the $\mathrm{N}$-terminus of ADM was significantly higher than for the anti-midregion and the anti-C-terminal antibody (NT-M vs. MR-M: HR $=0.212$ (CI $=0.712$ to 0.063$), p=0.0122$; NT-M vs. CT-M: HR $=0.285$ (CI $=0.0823$ to 0.979 ), $p=0.0462$ ). Similar results were obtained in a follow-up experiment with Fab and

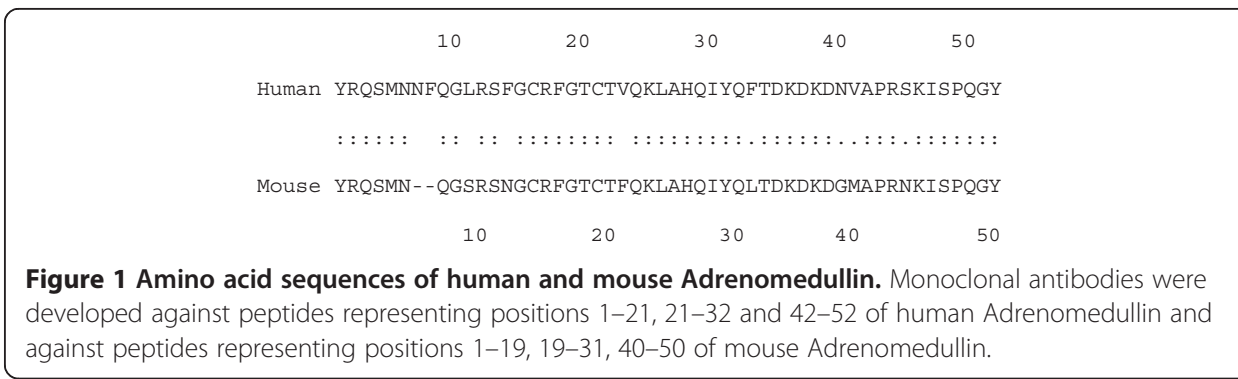



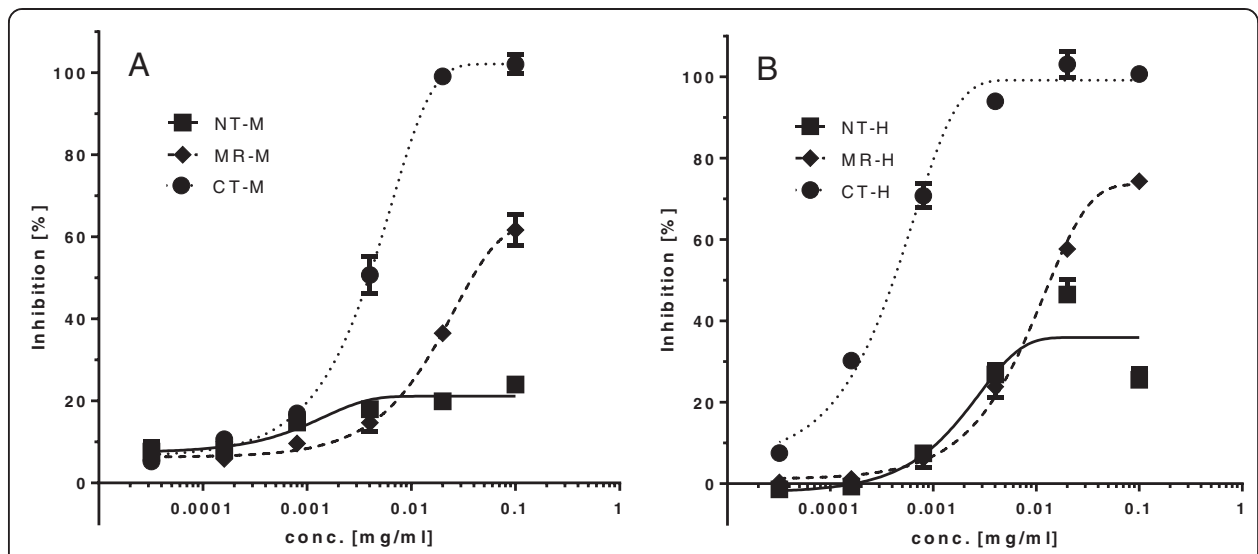

Figure 2 Dose/response curves for various anti-ADM antibodies affecting ADM-induced CAMP response in an ADM bioassay (antagonist activity). The monoclonal antibodies used were directed against the N-terminus (NT-M), mid-region (MR-M) and C-terminus (CT-M) of mouse ADM in the presence of $0.67 \mathrm{nM}$ mouse ADM (panel A), and directed against the N-terminus (NT-H), mid-region (MR-H) and C-terminus (CT-H) of human ADM in the presence of $5.63 \mathrm{nM}$ human ADM (panel B).

$\mathrm{F}(\mathrm{ab})_{2}$ fragments of the antibody against the N-terminus of ADM (Figure 4; Fab: $\mathrm{HR}=0.273(\mathrm{CI}=0.043$ to 0.356$), p=0.0017 ; \mathrm{F}(\mathrm{ab})_{2}: \mathrm{HR}=0.298(\mathrm{CI}=0.044$ to 0.354), $p=0.0025)$. When the antibody against the N-terminus of ADM was administered to healthy mice even at a 15 -fold-higher concentration than that in the CLP experiment, all animals survived and the physical condition of the animals was not impaired compared to control animals (data not shown).

When the antibody against the N-terminus of ADM was administered to healthy mice even at a 15-fold higher concentration than in the CLP experiment, all animals survived and the physical condition of the animals was not impaired compared to control animals (data not shown).

\section{Discussion}

In this study, we report that an antibody directed against the N-terminus of ADM substantially reduces mortality in a septic animal model, whereas antibodies against
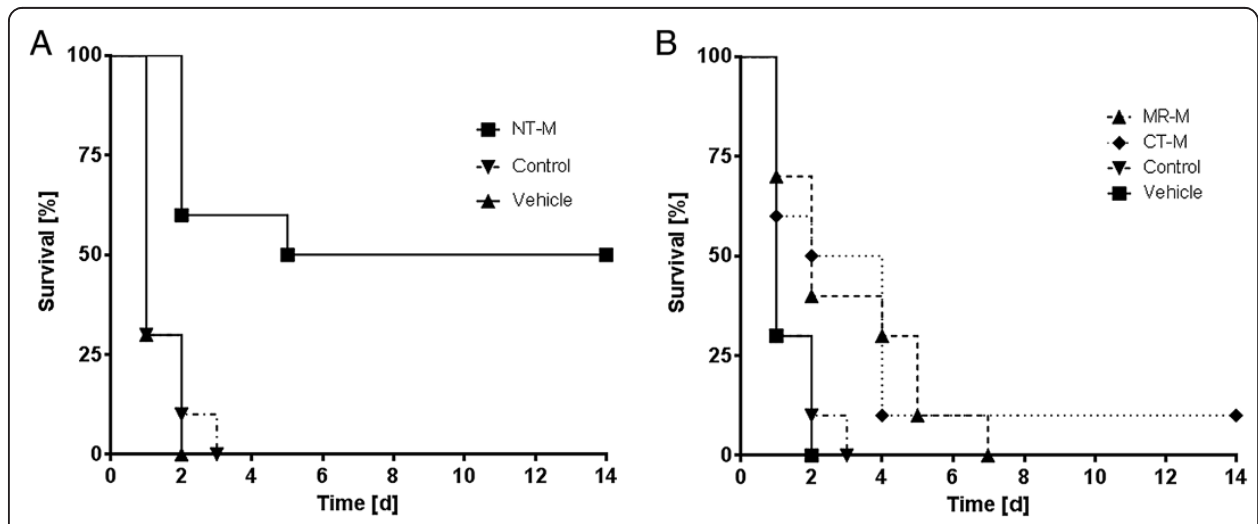

Figure 3 Survival rates of CLP mice treated with various antibodies. The monoclonal antibodies used were directed against the N-terminus (NT-M) (Panel A), and mid-region (MR-M) and C-terminus (CT-M) of mouse ADM (Panel B). An unspecific mouse lgG was used as control (shown in Panels $\mathbf{A}$ and $\mathbf{B}$ ). For statistics see main text. 


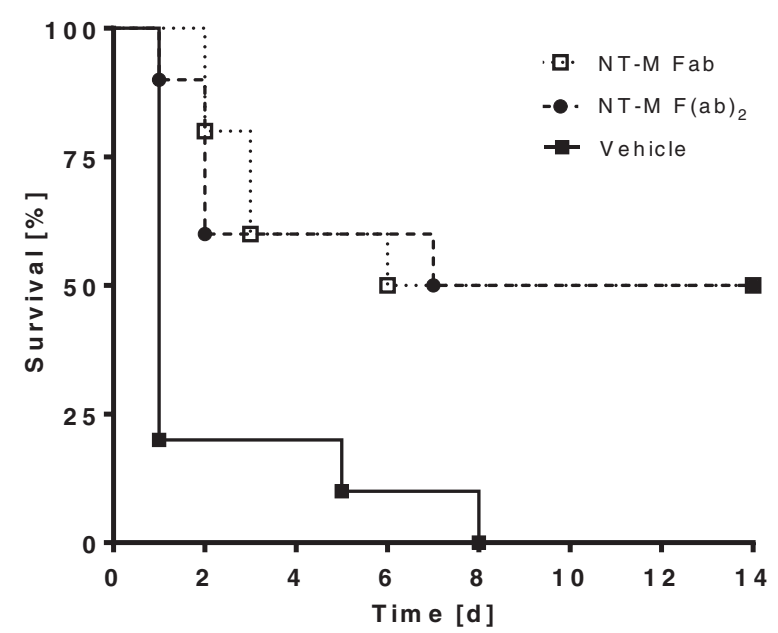

Figure 4 Survival rates of CLP mice treated with NT-M antibody fragments. Fab and $F(a b)_{2}$ fragments of the antibody directed against the N-terminus (NT-M) of ADM were tested. For statistics see main text.

other regions of ADM are far less efficacious. Anti-N-terminal antibodies only partially inhibit ADM agonist function in a bioassay.

It has been known that plasma ADM levels strongly increase with the severity of sepsis, severe sepsis, and septic shock, and that elevated levels are highly prognostic for fatal outcome [24-26]. This had suggested that ADM plays a role in the cascade of events happening during the progression of sepsis, leaving open the question, though, of whether ADM represents the 'fire' or the 'firemen', whether it is friend or foe in this process. ADM has been shown to be a key player in initiating the hyperdynamic response during the early stage of sepsis [12-14]. When sepsis proceeds to hypodynamic shock, vascular responsiveness to ADM fades, suggesting that reduced ADM function could be causal for progression of the disease. Consequently, supplementation of exogenous ADM has been tested in animal models as a possibility to reduce mortality from sepsis [12,18-21]. These attempts were successful. However, concerns have been raised with respect to the safety of this approach as ADM, due to its strong vasodilatory activity, might be harmful in certain situations, and thus, the therapeutic regime might be difficult to control [27]. Additionally, ADM as a small peptide is prone to proteolytic degradation and - as plasma protease activities increase and vary in sepsis patients [28] - it might not be an ideal drug structure by concept. Moreover, at least the group of Wang is convinced that ADM alone is not sufficiently efficacious, but coadministration of complement factor $\mathrm{H}$, an ADM binding protein, is necessary [12]. Development of such a two-compound drug appears challenging in several aspects.

ADM might not be beneficial under all circumstances in the progression of sepsis: In vitro experiments suggest that ADM has negative inotropic effects and cause impairment of cardiac function in sepsis: The contractility of cardiac myocytes isolated from LPS-treated rats was reduced compared to that in control animals, and addition of ADM (22-52), an ADM receptor antagonist peptide, reversed this effect [22]. With an anti-ADM antiserum, mortality of LPS-treated rats could be reduced [22]. It was interpreted that during the progression of sepsis, the role of ADM reverses from that of a compensatory mediator to a perpetuator of cardiodepression [29]. 
The anti-ADM antiserum used to successfully reduce mortality in septic rats was not further characterized; no information was gained concerning the concentration of anti-ADM antibodies in the antiserum, their affinities, their epitope specificities, and their agonist and antagonist activities.

We set out to systematically develop and characterize monoclonal antibodies directed against various epitopes of $\mathrm{ADM}$ and investigate their potential utility as drugs to reduce sepsis-associated mortality in a mouse CLP model. Antibodies against the C-terminal moiety of ADM were capable of fully inhibiting the ADM-induced cAMP response in an ADM receptor bioassay. This could have been expected as ADM (22-52) is known to be an effective ADM receptor antagonist. Less expected was our finding that antibodies against the N-terminal moiety of ADM inhibited ADM agonist activity maximally by only around $25 \%$. The level of inhibition did not change over almost three orders of magnitude of antibody concentration tested. It was exactly such an anti-N-terminal antibody as well as Fab and $\mathrm{F}(\mathrm{ab})_{2}$ fragments thereof, which substantially reduced mortality in a mouse CLP model. In contrast, an anti-C-terminal antibody did not strongly improve survival in this animal model. Thus, promotion of survival apparently requires on one hand a certain minimum level of functional ADM and on the other hand the reduction of excessively high concentrations of ADM. It appears paradoxical that both supplementation with $\mathrm{ADM}$, as shown previously [12,18-21], and antibodies against ADM, as we show here, can reduce mortality in septic animal models. We can only speculate about the mechanistic background of these observations: As ADM has an in vivo half-life of only 22 min [30], a relatively short increase of ADM levels, especially in the early phase of sepsis progression, might be beneficial. The reduction of ADM functionality by an anti-N-terminal antibody might be more relevant in the later phase, when excessive endogenous ADM production is associated with fatal outcome. Our results indicate that complete inhibition of ADM agonist activity during sepsis is not very efficacious, if at all, to improve survival. The mechanism leading to a substantially improved survival rate of CLP mice when treated with an anti-N-terminal antibody is not completely clear. We hypothesize that binding of the anti-N-terminal antibody to ADM still allows receptor binding, but less efficiently, and thus reduces the functionality of ADM so that excess levels, which have been suggested to become harmful during the progression of sepsis, then get functionally neutralized to a certain limited extent. Partial functional inhibition of ADM, on the other hand, leaves sufficient ADM available, which is required in the early hyperdynamic phase of sepsis and possibly later as well. It is not excluded that besides the functional modulation of ADM, the anti-N-terminal antibody influences the proteolytic decay of circulating ADM, since ADM is N-terminally susceptible to proteolytic degradation [31], and thereby prolongs its half-life and bioavailablity. In any case, the use of a defined anti-N-terminal antibody constitutes a novel approach to modulate the ADM pathway during the progression of sepsis, which has some obvious advantages over previously applied concepts involving ADM as a drug component: An antibody is less prone to proteolytic degradation than ADM peptide; elevated and varying proteolytic activity might in an uncontrolled manner affect peptide integrity in the circulation of sepsis patients. ADM is a very sticky molecule [32], and this might add risk in the drug production and application processes. Thirdly, concerns have been raised against the use of $\mathrm{ADM}$ as a drug since it is known as a strong vasodilator, and thus it might be 
difficult to define the therapeutic window and avoid potentially harmful effects outside this window. In contrast, the anti-N-terminal antibody appears safe as it did not impair healthy mice, even at a 15-fold-higher concentration than that successfully used in the CLP model. Presumably, this is due to a relatively small modulation of the ADM system. Finally, the development of monoclonal antibodies as drugs is a standard process nowadays. If it turns out that, as Wang's group suggests, in fact complement factor $\mathrm{H}$ must be coadministered with ADM to gain sufficient efficacy, then this represents another challenge for drug development, which we do not face with the development of a therapeutic antibody.

\section{Conclusions}

In conclusion, we have shown in an established septic mouse model a strongly beneficial effect on survival by use of an anti-N-terminal ADM antibody. The effect is due to its epitope specificity and is associated with partial inhibition of ADM agonist function. The results of this pilot study are a basis to further develop an alternative, advantageous way for drug development modulating the ADM pathway to finally reduce mortality during the progression of sepsis, which continues to be a strong unmet clinical need.

\section{Key messages}

The following are the key messages derived from this study:

- Anti-ADM antibodies have different antagonist activity in vitro depending on their epitope specificity.

- Antagonist activity is strong for anti-C-terminal antibodies, medium for antimidregional antibodies and weak for anti-N-terminal antibodies.

- Anti-ADM antibodies are significantly but differently efficacious in reducing mortality in CLP-treated mice depending on their epitope specificity.

- The anti-N-terminal antibody reduces mortality substantially, whereas antibodies against other regions of ADM are less potent.

\footnotetext{
Abbreviations

AMBP-1: Adrenomedullin binding protein 1; ADM: Adrenomedullin; BSA: Bovine serum albumin; CT-H: Mouse monoclonal antibody against the carboxyterminal region of human adrenomedullin; CT-M: Mouse monoclonal antibody against the carboxyterminal region of mouse adrenomedullin; CLP: Cecal ligation and puncture;

CRLR: Calcitonin receptor-like receptor; LPS: Lipopolysaccharide; MOF: Multiple organ failure; MR-H: Mouse monoclonal antibody against the midregion of human adrenomedullin; MR-M: Mouse monoclonal antibody against the midregion of mouse adrenomedullin; NT-H: Mouse monoclonal antibody against the aminoterminal region of human adrenomedullin; NT-M: Mouse monoclonal antibody against the aminoterminal region of mouse adrenomedullin; PBS: Phosphate buffered saline; RAMP: Receptor-activity modifying protein.
}

Competing interests

All authors hold shares of AdrenoMed AG. AdrenoMed AG holds patent rights on anti-ADM antibodies. JS, FH, and AB are employed by AdrenoMed AG.

All authors have made substantial contributions to the conception and design, or acquisition of data, or analysis and interpretation of data; all have been involved in drafting the manuscript or revising it critically for important intellectual content; and all have given final approval of the manuscript. In particular, AB developed the design of the study and evaluated the data, SK developed and characterized the antibodies and directed the animal studies, FH directed the bioassay and worked on the manuscript, and JS drafted the manuscript and participated in the design and evaluation of the study. 


\section{Acknowledgements}

We like to thank Dr. Martina Strebelow and Sonja Tietz from UNICUS Karlsburg OHG for their excellent technical service. This study was supported by grants from the Federal State of Brandenburg and European Regional Development Funds (EFRE).

\section{Author details}

${ }^{1}$ AdrenoMed AG, Neuendorfstr. 15a, Hennigsdorf 16761, Germany. ${ }^{2} \mathrm{ICl}$ GmbH, Berlin 10999, Germany.

Received: 9 October 2013 Accepted: 10 October 2013

Published: 29 October 2013

\section{References}

1. Angus DC, Linde-Zwirble WT, Lidicker J, Clermont G, Carcillo J, Pinsky MR (2001) Epidemiology of severe sepsis in the United States: analysis of incidence, outcome, and associated costs of care. Crit Care Med 29(7):1303-1310

2. Martin GS, Mannino DM, Eaton S, Moss M (2003) The epidemiology of sepsis in the United States from 1979 through 2000. N Engl J Med 348(16):1546-1554

3. Melamed A, Sorvillo FJ (2009) The burden of sepsis-associated mortality in the United States from 1999 to 2005 : an analysis of multiple-cause-of-death data. Crit Care 13(1):R28

4. Aziz M, Jacob A, Yang WL, Matsuda A, Wang P (2012) Current trends in inflammatory and immunomodulatory mediators in sepsis. J Leukoc Biol 93(3):329-42

5. Hotchkiss RS, Karl IE (2003) The pathophysiology and treatment of sepsis. N Engl J Med 348(2):138-150

6. Riedemann NC, Guo RF, Ward PA (2003) Novel strategies for the treatment of sepsis. Nat Med 9(5):517-524

7. Vincent $J \mathrm{~L}$ (2012) The rise and fall of drotrecogin alfa (activated). Lancet Infect Dis 12(9):649-651

8. Sprung CL, Annane D, Singer M, Moreno R, Keh D, Group CS (2011) Glucocorticoids in sepsis: dissecting facts from fiction. Crit Care 15(5):446

9. Brunkhorst FM, Engel C, Bloos F, Meier-Hellmann A, Ragaller M, Weiler N, Moerer O, Gruendling M, Oppert M, Grond S, Olthoff D, Jaschinski U, John S, Rossaint R, Welte T, Schaefer M, Kern P, Kuhnt E, Kiehntopf M, Hartog C, Natanson C, Loeffler M, Reinhart K, German Competence Network Sepsis (SepNet) (2008) Intensive insulin therapy and pentastarch resuscitation in severe sepsis. N Engl J Med 358(2):125-139

10. Abraham E (1999) Why immunomodulatory therapies have not worked in sepsis. Intensive Care Med 25(6):556-566

11. Wang P, Ba ZF, Cioffi WG, Bland Kl, Chaudry IH (1998) The pivotal role of adrenomedullin in producing hyperdynamic circulation during the early stage of sepsis. Arch Surg 133(12):1298-1304

12. Yang S, Zhou M, Chaudry $H$, Wang P (2002) Novel approach to prevent the transition from the hyperdynamic phase to the hypodynamic phase of sepsis: role of adrenomedullin and adrenomedullin binding protein-1. Ann Surg 236(5):625-633

13. Zhou M, Ba ZF, Chaudry IH, Wang P (2002) Adrenomedullin binding protein-1 modulates vascular responsiveness to adrenomedullin in late sepsis. Am J Physiol Regul Integr Comp Physiol 283(3):R553-560

14. Fowler DE, Yang S, Zhou M, Chaudry $I H$, Simms HH, Wang P (2003) Adrenomedullin and adrenomedullin binding protein-1: their role in the septic response. J Surg Res 109(2):175-181

15. Kitamura K, Kangawa K, Kawamoto M, Ichiki Y, Nakamura S, Matsuo H, Eto T (1993) Adrenomedullin: a novel hypotensive peptide isolated from human pheochromocytoma. Biochem Biophys Res Commun 192(2):553-560

16. Hinson JP, Kapas S, Smith DM (2000) Adrenomedullin, a multifunctional regulatory peptide. Endocr Rev 21(2):138-167

17. Beltowski J, Jamroz A (2004) Adrenomedullin-what do we know 10 years since its discovery? Pol J Pharmacol 56(1):5-27

18. Temmesfeld-Wollbruck B, Brell B, David I, Dorenberg M, Adolphs J, Schmeck B, Suttorp N, Hippenstiel S (2007) Adrenomedullin reduces vascular hyperpermeability and improves survival in rat septic shock. Intensive Care Med 33(4):703-710

19. Gonzalez-Rey E, Chorny A, Varela N, Robledo G, Delgado M (2006) Urocortin and adrenomedullin prevent lethal endotoxemia by down-regulating the inflammatory response. Am J Pathol 168(6):1921-1930

20. Zhou M, Maitra SR, Wang P (2007) Adrenomedullin and adrenomedullin binding protein-1 protect endothelium-dependent vascular relaxation in sepsis. Mol Med 13(9-10):488-494

21. Wu R, Higuchi S, Dong W, Ji Y, Zhou M, Marini CP, Ravikumar TS, Wang P (2009) Reversing established sepsis in rats with human vasoactive hormone adrenomedullin and its binding protein. Mol Med 15(1-2):28-33

22. Hyvelin JM, Shan Q, Bourreau JP (2002) Adrenomedullin: a cardiac depressant factor in septic shock. J Card Surg 17(4):328-335

23. Karpinich NO, Hoopes SL, Kechele DO, Lenhart PM, Caron KM (2011) Adrenomedullin Function in Vascular Endothelial Cells: Insights from Genetic Mouse Models. Curr Hypertens Rev 7(4):228-239

24. Hirata Y, Mitaka C, Sato K, Nagura T, Tsunoda Y, Amaha K, Marumo F (1996) Increased circulating adrenomedullin, a novel vasodilatory peptide, in sepsis. J Clin Endocrinol Metab 81(4):1449-1453

25. Ehlenz K, Koch B, Preuss P, Simon B, Koop I, Lang RE (1997) High levels of circulating adrenomedullin in severe illness: correlation with C-reactive protein and evidence against the adrenal medulla as site of origin. Experimental and Clinical Endocrinology \& Diabetes : Official Journal, German Society of Endocrinology [and] German Diabetes Association 105(3):156-162

26. Ueda S, Nishio K, Minamino N, Kubo A, Akai Y, Kangawa K, Matsuo H, Fujimura Y, Yoshioka A, Masui K, Doi N, Murao Y, Miyamoto S (1999) Increased plasma levels of adrenomedullin in patients with systemic inflammatory response syndrome. Am J Respir Crit Care Med 160(1):132-136

27. Westphal M, Sander J, Van Aken H, Ertmer C, Stubbe HD, Booke M (2006) [Role of adrenomedullin in the pathogenesis and treatment of cardiovascular dysfunctions and sepsis]. Anaesthesist 55(2):171-178

28. Colman RW (1989) The role of plasma proteases in septic shock. N Engl J Med 320(18):1207-1209 
29. Mittra S, Hyvelin JM, Shan Q, Tang F, Bourreau JP (2004) Role of cyclooxygenase in ventricular effects of adrenomedullin: is adrenomedullin a double-edged sword in sepsis? Am J Physiol Heart Circ Physiol 286(3):H1034-1042

30. Meeran K, O'Shea D, Upton PD, Small CJ, Ghatei MA, Byfield PH, Bloom SR (1997) Circulating adrenomedullin does not regulate systemic blood pressure but increases plasma prolactin after intravenous infusion in humans: a pharmacokinetic study. J Clin Endocrinol Metab 82(1):95-100

31. Lewis LK, Smith MW, Brennan SO, Yandle TG, Richards AM, Nicholls MG (1997) Degradation of human adrenomedullin(1-52) by plasma membrane enzymes and identification of metabolites. Peptides 18(5):733-739

32. Lewis LK, Smith MW, Yandle TG, Richards AM, Nicholls MG (1998) Adrenomedullin(1-52) measured in human plasma by radioimmunoassay: plasma concentration, adsorption, and storage. Clin Chem 44(3):571-577

doi:10.1186/2197-425X-1-3

Cite this article as: Struck et al:: Epitope specificity of anti-Adrenomedullin antibodies determines efficacy of mortality reduction in a cecal ligation and puncture mouse model. Intensive Care Medicine Experimental 2013 1:3.

Submit your manuscript to a SpringerOpen ${ }^{\circ}$ journal and benefit from:

- Convenient online submission

- Rigorous peer review

- Immediate publication on acceptance

- Open access: articles freely available online

- High visibility within the field

- Retaining the copyright to your article

Submit your next manuscript at $\gg$ springeropen.com 